\title{
Sanger and Next Generation Sequencing Approaches to Evaluate HIV-1 Virus in Blood Compartments
}

\author{
Andrea Arias, Pablo López, Raphael Sánchez, Yasuhiro Yamamura and Vanessa Rivera-Amill * \\ AIDS Research Infrastructure Program, Ponce Health Sciences University-Ponce Research Institute, \\ Puerto Rico 00716-2348, USA; aarias@psm.edu (A.A.); plopez@psm.edu (P.L.); rsanchez@psm.edu (R.S.); \\ bonyamam@gmail.com (Y.Y.) \\ * Correspondence: vrivera@psm.edu; Tel.: +1-787-841-5150
}

Received: 6 July 2018; Accepted: 6 August 2018; Published: 9 August 2018

\begin{abstract}
The implementation of antiretroviral treatment combined with the monitoring of drug resistance mutations improves the quality of life of HIV-1 positive patients. The drug resistance mutation patterns and viral genotypes are currently analyzed by DNA sequencing of the virus in the plasma of patients. However, the virus compartmentalizes, and different $\mathrm{T}$ cell subsets may harbor distinct viral subsets. In this study, we compared the patterns of HIV distribution in cell-free (blood plasma) and cell-associated viruses (peripheral blood mononuclear cells, PBMCs) derived from ART-treated patients by using Sanger sequencing- and Next-Generation sequencing-based HIV assay. $\mathrm{CD}^{+} \mathrm{CD}^{2} 5 \mathrm{RA}^{-} \mathrm{RO}^{+}$memory T-cells were isolated from PBMCs using a BD FACSAria instrument. HIV pol (protease and reverse transcriptase) was RT-PCR or PCR amplified from the plasma and the T-cell subset, respectively. Sequences were obtained using Sanger sequencing and Next-Generation Sequencing (NGS). Sanger sequences were aligned and edited using RECall software (beta v3.03). The Stanford HIV database was used to evaluate drug resistance mutations. Illumina MiSeq platform and HyDRA Web were used to generate and analyze NGS data, respectively. Our results show a high correlation between Sanger sequencing and NGS results. However, some major and minor drug resistance mutations were only observed by NGS, albeit at different frequencies. Analysis of low-frequency drugs resistance mutations and virus distribution in the blood compartments may provide information to allow a more sustainable response to therapy and better disease management.
\end{abstract}

Keywords: HIV-1; blood compartment; plasma; PBMCs; memory CD4+ T-cells; Sanger Sequencing; Next-Generation Sequencing

\section{Introduction}

Differences in drug penetration in various compartments within HIV infected patients under antiretroviral therapy (ART) may account for viral compartmentalization, low-level viral replication, and mutation [1-3]. While ART therapy can suppress plasma HIV viral load below the detection limits, specific $T$ cell compartments can remain as virus reservoirs, and the virus in different compartments have been shown to evolve independently [4-6]. The CD4 ${ }^{+}$T-cells are the primary targets of HIV, and due to the differences in drug distribution throughout the body, drugs resistance mutations may emerge, suggesting that HIV mutation patterns in plasma may not necessarily reflect those detected in the cell-associated compartment (CA) [7-9]. The factors discussed above together with patient non-adherence to treatment, drug toxicity, and antiretroviral treatment fatigue are associated with viral rebound [10]. Genotyping resistance testing has become an essential tool for improvement of HIV-1 ART outcomes [11]. HIV-1 genotyping is routinely performed by sequencing of the virus in the plasma of patients. Standard population-based Sanger sequencing may fail the detect low-frequency drug resistance mutations [12-14]. Next-Generation sequencing-based HIV assay is a new platform 
that allows monitoring low abundance viral variants, which may be involved in reduced susceptibility to ART treatment $[15,16]$. The objective of the present study was to evaluate the concordance of drug resistance mutations between plasma, peripheral blood mononuclear cells (PBMCs) and $\mathrm{CD} 4^{+}$memory T-cells $\left(\mathrm{CD}^{+} \mathrm{CD}^{+} \mathrm{CD} 45 \mathrm{RA}^{-} \mathrm{RO}^{+}\right)$by using the Sanger sequencing and NGS platforms.

\section{Methods}

The current study was conducted in accordance with the Declaration of Helsinki, and the protocol was certified by the Institutional Review Board of the Ponce Research Institute to be exempt from the federal policy for the protection of human subjects under the provision of use of existing data and specimens (plasma and PBMC's) (Protocol number: 140418-YY; date of approval: 03/28/2018). Peripheral blood samples $(4 \mathrm{~mL})$ were processed for viral load and complete blood counts from four HIV-1 positive individuals. The samples included in this study were selected from a bank of samples based on viral loads of at least 1000 copies $/ \mathrm{mL}$ and availability of stored PBMCs and a minimum $\mathrm{CD}^{+} \mathrm{T}$ cell count of 350 cells $/ \mu \mathrm{L}$. Viral load was determined using the COBAS ${ }^{\circledR}$ AmpliPrep/COBAS ${ }^{\circledR}$ TaqMan ${ }^{\circledR}$ HIV-1 Test version 2 using the COBAS ${ }^{\circledR}$ AmpliPrep Instrument for automated specimen processing and the COBAS ${ }^{\circledR}$ TaqMan $^{\circledR} 48$ Analyzer for automated amplification and detection (Roche Diagnostics, Indianapolis, IN, USA).

\subsection{Cell Sorting}

The monoclonal antibodies used for identification of the cell markers were as follows: CD45RA-FITC, CD3-PerCP, CD4-PECy7, and CD45RO-PE. Respective isotype controls were used for identifying marker-positive populations. Analysis and cell sorting were performed by using a BD FACSAria (BD Biosciences, San Jose, CA, USA). The purity of CD4 ${ }^{+} \mathrm{CD} 45 \mathrm{RA}^{-} \mathrm{RO}^{+} \mathrm{T}$-cells prepared by cell-sorting was consistent at $>95 \%$ (Figure 1).
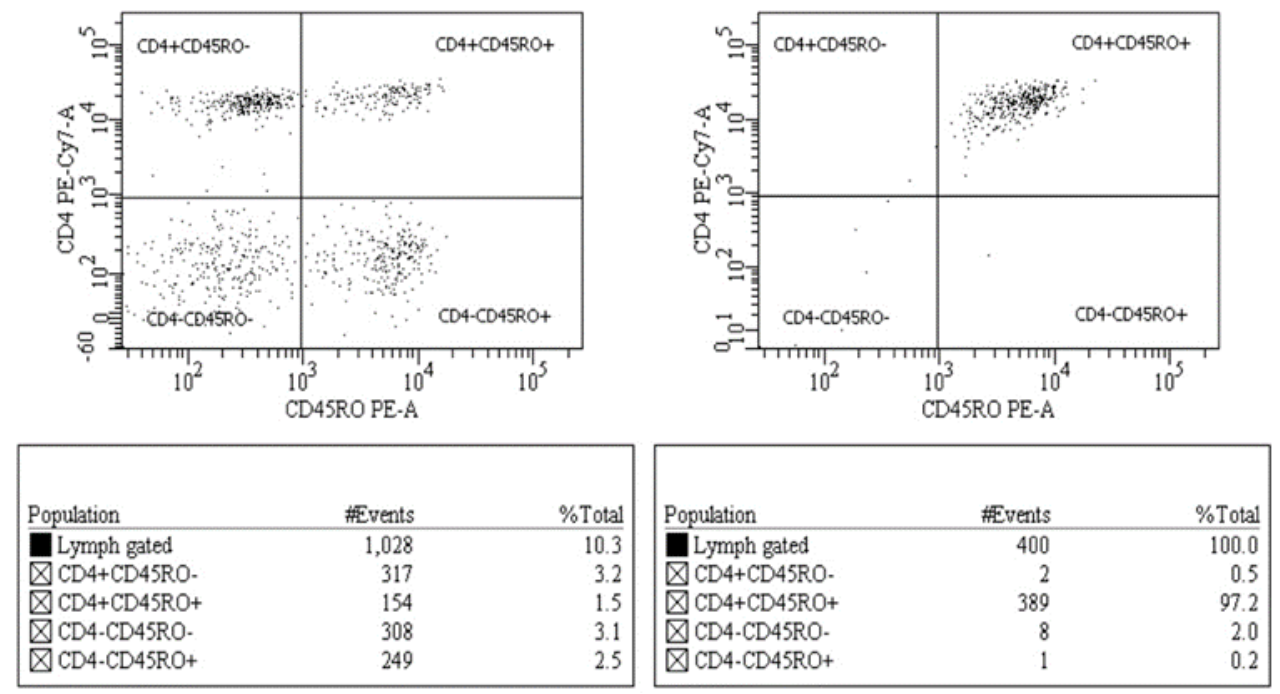

Figure 1. Analysis and cell sorting of $\mathrm{CD}^{+} \mathrm{T}$-cells. The lymphocyte population was further identified as $\mathrm{CD}^{+} \mathrm{CD}^{+} \mathrm{T}$-cells, each of which was then sub-classified into the memory $\left(\mathrm{CD} 4^{+} \mathrm{CD} 45 \mathrm{RA}^{-} \mathrm{RO}^{+}\right)$or naïve $\left(\mathrm{CD}^{+} \mathrm{CD} 45 \mathrm{RA}^{+} \mathrm{RO}^{-}\right)$subsets for cell-sorting. Purity of a sorted cell population was $>95 \%$.

\subsection{Nucleotide Acid Purification and PCR Amplification}

After the cell sorting procedure, HIV-1 RNA and DNA was purified from the plasma and corresponding T-cell subsets, using QIAamp viral RNA Mini Kit and QIAamp DNA Blood Mini Kit (QIAGEN, Hilden, Germany), respectively, according to the manufacturer's recommendations. Purified RNA and DNA were RT-PCR and PCR amplified by using the QIAGEN OneStep RT-PCR Kit (QIAGEN) and FastStart PCR Master (Sigma-Aldrich, Mannheim, Germany), respectively, according 
to our WHO accredited HIV-1 genotyping protocols. Briefly, first round RT-PCR conditions were as follows: $10 \mu \mathrm{L}$ of purified RNA was reverse transcribed at $50{ }^{\circ} \mathrm{C}$ for $40 \mathrm{~min}$, inactivation at $94{ }^{\circ} \mathrm{C}$ for $15 \mathrm{~min}$, followed by $35 \mathrm{cycles}$ of $94^{\circ} \mathrm{C}$ for $30 \mathrm{~s}, 53^{\circ} \mathrm{C}$ for $30 \mathrm{~s}$, and $72{ }^{\circ} \mathrm{C}$ for $2 \mathrm{~min}$ with a final extension at $72{ }^{\circ} \mathrm{C}$ for $10 \mathrm{~min}$. The first-round amplicon $(2 \mu \mathrm{L})$ was re-amplified using the FastStart PCR Master (Sigma-Aldrich) under the conditions as follow: $95^{\circ} \mathrm{C}$ for $15 \mathrm{~min}$ followed by 35 cycles of $\left(94{ }^{\circ} \mathrm{C}\right.$ for $15 \mathrm{~s}, 53^{\circ} \mathrm{C}$ for $30 \mathrm{~s}$, and $72{ }^{\circ} \mathrm{C}$ for $2 \mathrm{~min}$ ) and a final elongation at $72{ }^{\circ} \mathrm{C}$ for $10 \mathrm{~min}$. For DNA samples, both first round (10 $\mu \mathrm{L}$ of purified DNA) and second round ( $2 \mu \mathrm{L}$ of first round PCR product) PCR amplification was carried out using the FastStart PCR master as described above.

Table 1 lists the primers used for the PCR (Sanger/NGS) procedures. The conditions of PCR to NGS procedures were similar to Sanger with some modifications in the amplification step $\left(94{ }^{\circ} \mathrm{C}\right.$ for $30 \mathrm{~s}, 55^{\circ} \mathrm{C}$ for $30 \mathrm{~s}$, and $72{ }^{\circ} \mathrm{C}$ for $2 \mathrm{~min}$ ). Sanger sequences were determined by using an ABI 3730xl automated DNA Analyzer sequencer (Thermo Fisher Scientific Waltham, MA, USA).

Table 1. Primers used for RT-PCR and PCR procedures.

\begin{tabular}{|c|}
\hline Sanger \\
\hline $\begin{array}{c}\text { First Round } \\
\text { Forward (Protease):5'-TGAARGAITGYACTGARAGRCAGGCTAAT-3' } \\
\text { Reverse (Protease): 5'-AYCTIATYCCTGGTGTYTCATTRTT-3' } \\
\text { Forward (RT): 5'-TTTYAGRGARCTYAATAARAGAACTCA-3' } \\
\text { Reverse (RT): 5'-CCTCITTYTTGCATAYTTYCCTGTT-3' } \\
\text { Second Round } \\
\text { Forward (Protease): 5'-YTCAGRCAGRCCRGARCCAACAGC-3' } \\
\text { Reverse (Protease): 5'-CTGGTGTYTCATTRTTKRTACTAGGT-3' } \\
\text { Forward (RT): 5'- TTYTGGGARGTYCARYTAGGRATACC-3' } \\
\text { Reverse (RT): 5'- GGYTCTTGRTAAATTTGRTATGTCCA-3' }\end{array}$ \\
\hline NGS \\
\hline $\begin{array}{c}\text { PR-INNER_F } \\
\text { 5'-TCGTCGGCAGCGTCAGATGTGTATAAGAGACAGCTTTAACTTCCCTCAGGTCACTCT-3' } \\
\text { RT-1_R } \\
\text { 5'-GTCTCGTGGGCTCGGAGATGTGTATAAGAGACAGGTCAATGGCCATTGTTTAACTTTTGG-3' } \\
\text { RT-1_F } \\
\text { 5'-TCGTCGGCAGCGTCAGATGTGTATAAGAGACAGCCAAAAGTTAAACAATGGCCATTGAC-3' } \\
\text { PRNEWIN_R } \\
\text { 5'-GTCTCGTGGGCTCGGAGATGTGTATAAGAGACAGCTGGTGTYTCATTRTTKRTACTAGGT-3' } \\
\text { 5FP127_F } \\
\text { 5'-TCGTCGGCAGCGTCAGATGTGTATAAGAGACAGATACTGCATTTACCATACCTAG-3' } \\
\text { 3F262_R } \\
\text { 5'-GTCTCGTGGGCTCGGAGATGTGTATAAGAGACAGTCCCACTAACTTCTGTATGTC-3' }\end{array}$ \\
\hline
\end{tabular}

\subsection{Sequencing and Phylogenetic Analyses}

The RECall software (beta v3.03, the University of British Columbia, Vancouver, BC, Canada) was used to align and edit the sequences [17]. Drug resistance mutations were evaluated by using the Stanford HIV database [18]. To evaluate possible sample contamination maximum likelihood phylogenetic tree of HIV-1 pol gene (protease and reverse transcriptase) from samples processed by Sanger sequencing and NGS-based methods (consensus 20\%) was created by using MEGA software v6 under a General Time-Reversible (GTR) nucleotide substitution model with a gamma-distributed rate variation, which was suggested by Modeltest, and a re-sampling process (100 bootstraps) (Figure 2) [19]. The Sanger sequences and NGS sequences at the $20 \%$ threshold were submitted to Gen Bank with accession numbers: MH328213-MH328229, MH496618-MH49624. The NGS sequences were deposited at the National Center for Biotechnology Information Sequence Read Archive with accession number: PRJNA479460. 


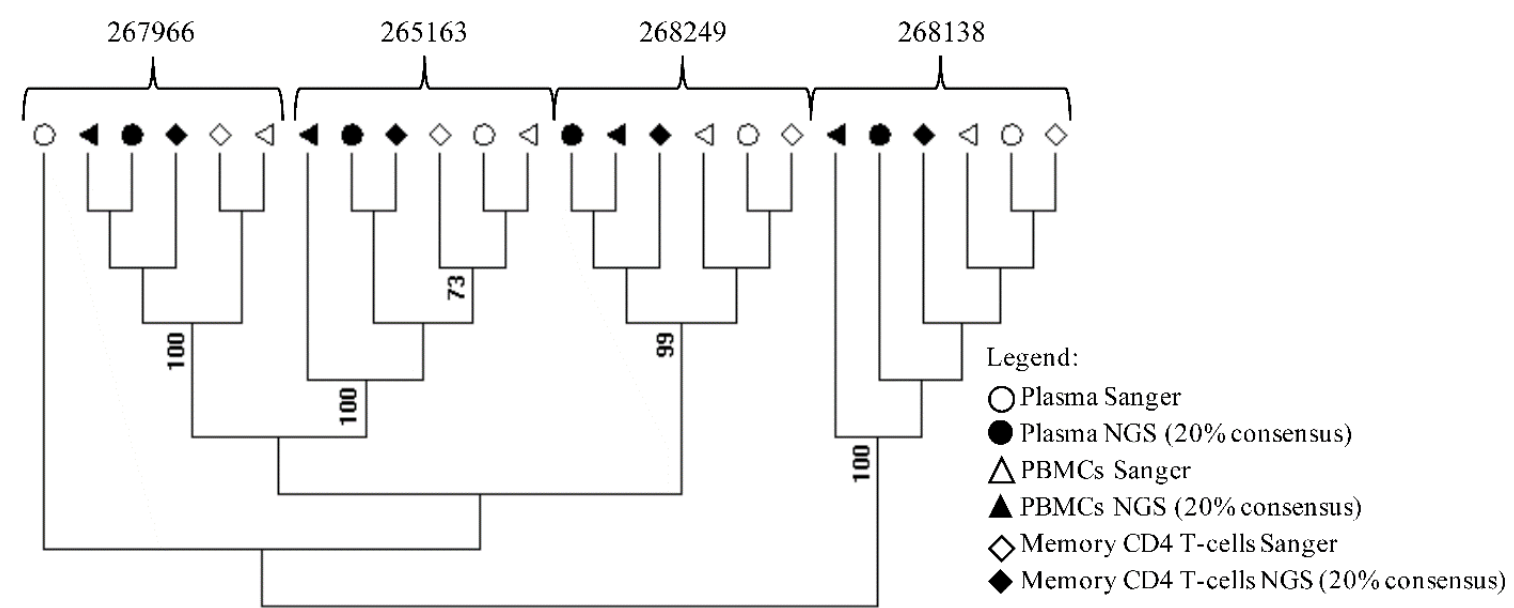

Figure 2. Phylogenetic assessment of cross-contamination in study samples. An HIV-1 pol gene (protease and reverse transcriptase) maximum likelihood tree was created by using MEGA software v6 from samples processed by Sanger- and NGS-based methods (consensus 20\%). The blood compartment and sequence methodology are indicated by symbols.

For NGS library construction, the first round PCR was re-amplified using amplicon primers containing the MiSeq (Illumina, Inc., San Diego, CA, USA) adapter sequences and the HIV-1 protease/reverse transcriptase (RT) locus-specific sequences. The samples were processed according to the 16S Metagenomic Sequencing Library Preparation guide (Illumina, LLC, Inc., San Diego, CA, USA) [20]. Briefly, the second round PCR was cleaned using magnetic beads and $80 \%$ ethanol, a third round PCR was performed to add unique barcodes to each sample, and the PCR product was cleaned one more time with magnetic beads and $80 \%$ ethanol. The barcoded amplicons were quantified using a Qubit 2.0 fluorometer and a Qubit dsDNA HS assay kit (Thermo Fisher Scientific Waltham, MA, USA)) and normalized to a $4 \mathrm{nM}$ concentration. After normalization, samples were pooled, and diluted to $4 \mathrm{pM}$ and heated to $96^{\circ} \mathrm{C}$ for $2 \mathrm{~min}$ and $30 \mu \mathrm{L}$ of the library were substituted with PhiX (12.5 pM). The denatured library was loaded on the Illumina MiSeq chip and a sequencing run of $2 \times 250 \mathrm{bp}$ MiSeq paired-end was performed. The resulting fastq files, Read 1 and Read 2 from each sample, were merged using FLASH software with the -M 550 and -O parameters [21]. The merged files were quality filtered using Trim Galore! with a minimal length of $360 \mathrm{bp}$, the option for filtering the Illumina adapter sequences (-illumina) and minimal error rate of 0.05 [22]. The InDelFixer aligner was used for aligning the reads to the reference sequences with the following options: -q 30,-illumina and -sensitive options [23]. Each sample has three fragments, protease (codon 1 of protease to 21 of RT), RT beginning (codon 15 to 141 of RT) and RT middle (codon 125 to 267 of RT) and all fragments were aligned to their corresponding sequences of the pol gene using the HIV-1 HXB2 reference sequence. The resulting sam files were converted to bam files, sorted and indexed using samtools, and the sorted bam files were converted to fastq files using the bamtools software [24,25]. The resulting fastq files were analyzed with Hydra Web (Government of Canada, Ottawa, Canada) with 20\% and 5\% sensitivity threshold for reporting low-frequency variants [26-28] We used the default target coverage (10,000 reads) and filtering settings (length cutoff: 100; score cutoff: 30) in HyDRA [29].

\section{Results and Discussion}

Sorting of $\mathrm{CD}^{+}{ }^{+} \mathrm{CD} 45 \mathrm{RA}^{-} \mathrm{RO}^{+} \mathrm{T}$ cells resulted in greater than $95 \%$ purity, indicating the isolation of the desired T cell population (Figure 1). Phylogenetic analysis of sequences generated using Sanger and NGS at the $20 \%$ threshold revealed that all samples formed well-defined clusters (Figure 2). Only the Sanger plasma sample from 267966 separates form its cluster.

Table 2 summarizes the plasma HIV- 1 viral loads, CD4 ${ }^{+}$T-cell counts and PCR amplification results of the four samples included in this study. Overall, our results show a high correlation between 
Sanger sequencing and NGS results between intra-patient cell-free (CF) and cell-associated (CA) virus by using NGS at 20\% consensus. However, in sample 267966 major resistance mutations (M184V, E138EA) were only detected in CA virus (NGS/Sanger) and plasma NGS (Table 2).

Table 2. Summary of sample viral load, $\mathrm{CD} 4^{+} \mathrm{T}$-cell counts and the mutations detected by Sanger sequencing and Next-Generation Sequencing. High correlation between Sanger sequencing and NGS-based HIV assay (consensus 20\%) was observed in major resistance mutations analyses.

\begin{tabular}{|c|c|c|}
\hline Samples & $\begin{array}{c}\text { Protease Major Resistance } \\
\text { Mutations }\end{array}$ & $\begin{array}{c}\text { RT Major Resistance } \\
\text { Mutations }\end{array}$ \\
\hline \multicolumn{3}{|l|}{267966 (Female) } \\
\hline \multicolumn{3}{|l|}{ Viral load: 1450 copies $/ \mathrm{mL}$} \\
\hline \multicolumn{3}{|l|}{$\mathrm{CD}^{+} \mathrm{T}$ cell counts: 649 cells $/ \mu \mathrm{L}$} \\
\hline \multicolumn{3}{|l|}{ Antiretroviral therapy: Yes } \\
\hline Plasma Sanger & none & none \\
\hline Plasma NGS (consensus 20\%) & none & M184V, E138EA \\
\hline PBMCs Sanger & none & M184V, E138A \\
\hline PBMC's NGS (consensus 20\%) & none & M184MV, E138EA \\
\hline $\mathrm{CD} 4^{+}$memory T-cells Sanger & none & M184V, E138A \\
\hline $\mathrm{CD}^{+}{ }^{+}$memory T-cells NGS (consensus $20 \%$ ) & none & M184V, E138A \\
\hline \multicolumn{3}{|l|}{268138 (Male) } \\
\hline \multicolumn{3}{|l|}{ Viral load: 12,500 copies $/ \mathrm{mL}$} \\
\hline \multicolumn{3}{|l|}{$\mathrm{CD}^{+} \mathrm{T}$ cell counts: 937 cells $/ \mu \mathrm{L}$} \\
\hline \multicolumn{3}{|l|}{ Antiretroviral therapy: Not available } \\
\hline Plasma Sanger & none & none \\
\hline Plasma NGS (consensus 20\%) & none & none \\
\hline PBMCs Sanger & none & none \\
\hline PBMCs NGS (consensus 20\%) & none & none \\
\hline $\mathrm{CD}^{+}{ }^{+}$memory T-cells Sanger & none & none \\
\hline $\mathrm{CD}^{+}{ }^{+}$memory T-cells NGS (consensus $20 \%$ ) & none & none \\
\hline \multicolumn{3}{|l|}{275163 (Female) } \\
\hline \multicolumn{3}{|l|}{ Viral load: 16,105 copies /mL } \\
\hline \multicolumn{3}{|l|}{$\mathrm{CD}^{+} \mathrm{T}$ cell counts: 369 cells $/ \mu \mathrm{L}$} \\
\hline \multicolumn{3}{|l|}{ Antiretroviral therapy: Yes } \\
\hline Plasma Sanger & none & none \\
\hline Plasma NGS (consensus 20\%) & none & none \\
\hline PBMCs Sanger & none & none \\
\hline PBMCs NGS (consensus 20\%) & none & none \\
\hline $\mathrm{CD}^{+}{ }^{+}$memory T-cells Sanger & none & none \\
\hline $\mathrm{CD}^{+}$memory T-cells NGS (consensus $20 \%$ ) & none & none \\
\hline \multicolumn{3}{|l|}{268249 (Female) } \\
\hline \multicolumn{3}{|l|}{ Viral load: 32,468 copies/mL } \\
\hline \multicolumn{3}{|l|}{$\mathrm{CD}^{+} \mathrm{T}$ cell counts: 511 cells $/ \mu \mathrm{L}$} \\
\hline \multicolumn{3}{|l|}{ Antiretroviral therapy: Yes } \\
\hline Plasma Sanger & none & none \\
\hline Plasma NGS (consensus 20\%) & none & none \\
\hline PBMCs Sanger & none & none \\
\hline PBMCs NGS (consensus 20\%) & none & none \\
\hline $\mathrm{CD}^{+}$memory T-cells Sanger & none & none \\
\hline $\mathrm{CD}^{+}{ }^{+}$memory T-cells NGS (consensus $20 \%$ ) & none & none \\
\hline
\end{tabular}

The mutations were detected consistently in CA virus when comparing both methodologies. The discrepancy between CF and CA may result from the low viral load in the sample 267966 as demonstrated by others [30-32]. The nucleoside reverse transcriptase inhibitor (NRTI) mutation M184V causes high resistance to lamivudine (3TC) and emtricitabine (FTC), meanwhile, the non-nucleoside reverse transcriptase inhibitor mutation E138EA causes low-level of resistance to rilpivirine (RPV) [33-35]. Neither Sanger sequencing nor NGS at the 20\% consensus identified the major resistance 
mutations in CF and CA virus in the samples of 268138, 275163 and 268249 (Table 2). Some accessory mutations, not currently included in the list of surveillance drug resistance mutations (SDRMs) were only observed by NGS, albeit at a different frequency in the data analysis by using $5 \%$ threshold (Table 3). In the sample 267966, the mutations M184V, E138A and E138EA were observed at high frequency by NGS in both CF and CA virus. Interestingly, the V179I mutation was only observed at high frequency $(41.47 \%)$ in NGS-PBMCs. The accessory mutation A71V, associated with increased viral replication, was detected by Sanger and NGS in all compartments of sample 268138. The highly polymorphic accessory mutation K20R, associated with increased replication fitness in strain with PI-resistance mutations, was observed in all compartments of the sample 275163 by NGS only when using the $5 \%$ consensus [36]. Also, Sanger did not detect the accessory mutation L10V in the sample 268249 , while it was detected at low-frequency $(12.69 \%)$ by NGS (Table 3).

Table 3. Mutations detected by Next-Generation Sequencing. The threshold for data analysis was set at $5 \%$. Protease and RT genes were analyzed and the table includes the gene and compartment with drug resistance mutations detected at the 5\% threshold. NP indicates that high frequency mutations were not present in the samples analyzed. Letters in bold indicate drug resistance mutations that were also detected by Sanger sequencing. (-) indicates not applicable.

\begin{tabular}{|c|c|c|c|c|c|c|c|c|}
\hline Sample & Gene & Classification & Surveillance & WT & Position & Mutation & Frequency & Coverage \\
\hline \multicolumn{9}{|l|}{267966} \\
\hline \multirow{3}{*}{ Plasma } & RT & NRTI & Yes & $\mathbf{M}$ & 184 & $\mathbf{V}$ & 99.4 & 46,490 \\
\hline & RT & NNRTI & No & E & 138 & A & 99.29 & 55,090 \\
\hline & RT & NRTI & Yes & M & 184 & V & 42.23 & 69,897 \\
\hline \multirow[t]{2}{*}{ PBMCs } & RT & NNRTI & No & E & 138 & $\mathbf{A}$ & 42.29 & 69,891 \\
\hline & RT & Other & No & V & 179 & I & 41.47 & 69,896 \\
\hline \multirow{2}{*}{$\mathrm{CD}^{+}{ }^{+}$memory T-cells } & RT & NRTI & Yes & $\mathbf{M}$ & 184 & $\mathbf{V}$ & 99.12 & 54,457 \\
\hline & RT & NNRTI & No & E & 138 & A & 99.38 & 54,452 \\
\hline \multicolumn{9}{|l|}{268249} \\
\hline Plasma & $\mathrm{PR} / \mathrm{RT}$ & - & - & WT & - & NP & - & - \\
\hline PBMCs & $\mathrm{PR} / \mathrm{RT}$ & - & - & WT & - & NP & - & - \\
\hline $\mathrm{CD}^{+}{ }^{+}$memory T-cells & PR & Other & No & $\mathrm{L}$ & 10 & $\mathrm{~V}$ & 12.69 & 9382 \\
\hline \multicolumn{9}{|l|}{268138} \\
\hline Plasma & PR & Other & No & A & 71 & $\mathbf{V}$ & 99.17 & 20,609 \\
\hline PBMCs & PR & Other & No & A & 71 & $\mathbf{V}$ & 98.64 & 66,474 \\
\hline $\mathrm{CD}^{+}$memory T-cells & PR & Other & No & A & 71 & $\mathbf{V}$ & 98.49 & 79,020 \\
\hline \multicolumn{9}{|l|}{275163} \\
\hline Plasma & PR & Other & No & K & 20 & $\mathbf{R}$ & 23.13 & 49,598 \\
\hline PBMCs & PR & Other & No & K & 20 & $\mathbf{R}$ & 97.03 & 46,084 \\
\hline $\mathrm{CD}^{+}{ }^{+}$memory T-cells & PR & Other & No & K & 20 & $\mathbf{R}$ & 96.9 & 33,222 \\
\hline
\end{tabular}

The purpose of this study was to assess the concordance between Sanger sequencing and NGS in the identification of drug resistance mutations in other compartments in addition to plasma. Overall, our results show a high correlation between Sanger sequencing and NGS results between CF and CA at the $20 \%$ threshold. We only detected one exception in the plasma from sample 267966, which is the sample with low viral load (1450 copies/mL) [37]. As expected, we observed additional drug resistance mutations in the $5 \%$ threshold analysis, and there was also a correlation between the results obtained by Sanger sequencing and NGS. While virus recovered from plasma is most commonly used for HIV-1 Sanger genotyping, HIV-1 in T-cell compartments of the same patient often present different patterns of mutations and high rates of recombination [38-41]. Previous studies demonstrated that memory $\mathrm{CD}_{4}^{+}$T-cell compartment in HIV-1 infected individuals under ART treatment contain high levels of proviral HIV-1, which makes the most significant contribution to the viral reservoir [42-44]. The prevalence of high frequency of mutations only in CA virus may be interpreted as the consequence of cumulative ART history of each patient $[45,46]$. Even though previous studies have indicated minor differences in drug resistance mutation patterns between HIV-1 in plasma versus viral cDNA in 
PBMCs of the same individual, it is assumed that both sources generally yield identical genotyping results $[32,47,48]$. Nevertheless, low-frequency mutations may emerge in patients with inadequate treatment management [49-51]. Recently, NGS sequencing has been proposed as an alternative to sequencing-based methods to identify mutations associated with resistance to antiretrovirals [52,53]. The NGS-based HIV assay is a new platform that allows the monitoring of low abundance viral variants. While the significance of these variants is presently unknown, they may be involved in reduced susceptibility to ART treatment. This technology reduces the turnaround time, and cost per nucleotide sequenced dramatically $[15,16,54]$. Analysis of low-frequency drug resistance mutations and virus distribution in the blood compartments may provide information allowing a more sustainable response to therapy and better disease management. The observation that in some cases HIV-1 in different compartments may have different combinations of mutations indicate that pro-viral DNA in PBMCs and $\mathrm{CD} 4^{+} \mathrm{CD} 45 \mathrm{RA}^{-} \mathrm{RO}^{+}$memory T-cells may affect the genotyping results by contributing with additional drugs resistance mutations. Though recent studies raised questions regarding the clinical utility of NGS for genotyping purposes $[55,56]$, the analysis of low-frequency drug resistance mutations and virus distribution in the blood compartments may provide information allowing a more sustainable response to therapy and better disease management. In newly diagnosed patients with no drug experience, analyzing the blood compartments using NGS may provide information on transmitted drug resistance mutations. Additional research is needed to determine the significance of the low abundance mutations detected by NGS.

\section{Conclusion}

We compared HIV drug resistance mutation genotyping by Sanger and NGS methodologies in plasma and other blood compartments. Our results show a high correlation between the two methodologies for detecting major DRMs in the various compartments from the same patient at the $20 \%$ threshold. At the 5\% threshold, we also detected a correlation in the detection of both surveillance and non-surveillance mutations. Also, a low-frequency drug-resistance mutation was detected only by NGS in the cell-associated compartment. The clinical relevance of the detection of cell-associated low-frequency drug resistance mutations by NGS needs to be assessed.

Author Contributions: A.A., P.L. and Y.Y. designed the study. R.S. acquired the sequencing data. A.A., P.L. and R.S. analyzed and interpreted the data. A.A., P.L. and V.R.-A. wrote the manuscript. V.R.-A. offered advice in the writing and revising of the manuscript. All of the authors approved the final version of the manuscript.

Acknowledgments: The study was supported by the AIDS Research Infrastructure Program (NIMHD RCMI Program; NIMHD-G12-MD007579).

Conflicts of Interest: The authors declare no conflict of interest.

\section{References}

1. Svicher, V.; Ceccherini-Silberstein, F.; Antinori, A.; Aquaro, S.; Perno, C.F. Understanding HIV compartments and reservoirs. Curr. HIV/AIDS Rep. 2014, 11, 186-194. [CrossRef] [PubMed]

2. Chun, T.W.; Fauci, A.S. HIV reservoirs: Pathogenesis and obstacles to viral eradication and cure. AIDS 2012, 26, 1261-1268. [CrossRef] [PubMed]

3. Moreno-Gamez, S.; Hill, A.L.; Rosenbloom, D.I.; Petrov, D.A.; Nowak, M.A.; Pennings, P.S. Imperfect drug penetration leads to spatial monotherapy and rapid evolution of multidrug resistance. Proc. Natl. Acad. Sci. USA 2015, 112. [CrossRef] [PubMed]

4. Potter, S.J.; Lemey, P.; Achaz, G.; Chew, C.B.; Vandamme, A.M.; Dwyer, D.E.; Dwyer, D.E.; Saksena, N.K. HIV-1 compartmentalization in diverse leukocyte populations during antiretroviral therapy. J. Leukoc. Biol. 2004, 76, 562-570. [CrossRef] [PubMed]

5. Shen, C.; Ding, M.; Craigo, J.K.; Tarwater, P.; Chatterjee, R.; Roy, P.; Pratima, R.; Subhasish, K.G.; Bibhuti, S.; Dolonchapa, M.; et al. Genetic characterization of HIV-1 from semen and blood from clade C-infected subjects from India and effect of therapy in these body compartments. Virology 2010, 401, 190-196. [CrossRef] [PubMed] 
6. Brown, R.J.; Peters, P.J.; Caron, C.; Gonzalez-Perez, M.P.; Stones, L.; Ankghuambom, C.; Kemebradikumo, P.; McClure, C.P.; George, A.; Stephen, T.; et al. Intercompartmental recombination of HIV-1 contributes to env intrahost diversity and modulates viral tropism and sensitivity to entry inhibitors. J. Virol. 2011, 85, 6024-6037. [CrossRef] [PubMed]

7. Martinez-Picado, J.; Deeks, S.G. Persistent HIV-1 replication during antiretroviral therapy. Curr. Opin. HIV AIDS 2016, 11, 417-423. [CrossRef] [PubMed]

8. Wong, J.K.; Hezareh, M.; Gunthard, H.F.; Havlir, D.V.; Ignacio, C.C.; Spina, C.A.; Richman, D.D. Recovery of replication-competent HIV despite prolonged suppression of plasma viremia. Science 1997, 278, 1291-1295. [CrossRef] [PubMed]

9. Lee, G.Q.; Lichterfeld, M. Diversity of HIV-1 reservoirs in CD4 ${ }^{+}$T-cell subpopulations. Curr. Opin. HIV AIDS 2016, 11, 383-387. [CrossRef] [PubMed]

10. Paquet, A.C.; Baxter, J.; Weidler, J.; Lie, Y.; Lawrence, J.; Kim, R.; Michael, B.; Eoin, C.; Colombe, C. Differences in reversion of resistance mutations to wild-type under structured treatment interruption and related increase in replication capacity. PLoS ONE 2011, 6. [CrossRef] [PubMed]

11. Liu, T.F.; Shafer, R.W. Web resources for HIV type 1 genotypic-resistance test interpretation. Clin. Infect. Dis. 2006, 42, 1608-1618. [CrossRef] [PubMed]

12. Chen, X.; Zou, X.; He, J.; Zheng, J.; Chiarella, J.; Kozal, M.J. HIV Drug Resistance Mutations (DRMs) Detected by Deep Sequencing in Virologic Failure Subjects on Therapy from Hunan Province, China. PLoS ONE 2016, 11. [CrossRef] [PubMed]

13. Palmer, S.; Kearney, M.; Maldarelli, F.; Halvas, E.K.; Bixby, C.J.; Bazmi, H.; Rock, D.; Falloon, J.; Davey, R.T.J.; Dewar, R.L.; et al. Multiple, linked human immunodeficiency virus type 1 drug resistance mutations in treatment-experienced patients are missed by standard genotype analysis. J. Clin. Microbiol. 2005, 43, 406-413. [CrossRef] [PubMed]

14. Parikh, U.M.; McCormick, K.; van Zyl, G.; Mellors, J.W. Future technologies for monitoring HIV drug resistance and cure. Curr. Opin. HIV AIDS 2017, 12, 182-189. [CrossRef] [PubMed]

15. Gibson, R.M.; Schmotzer, C.L.; Quinones-Mateu, M.E. Next-Generation Sequencing to Help Monitor Patients Infected with HIV: Ready for Clinical Use? Curr. Infect. Dis. Rep. 2014, 16. [CrossRef] [PubMed]

16. Dudley, D.M.; Chin, E.N.; Bimber, B.N.; Sanabani, S.S.; Tarosso, L.F.; Costa, P.R.; Sauer, M.M.; Kallas, E.G.; O'Connor, D.H. Low-cost ultra-wide genotyping using Roche/454 pyrosequencing for surveillance of HIV drug resistance. PLoS ONE 2012, 7. [CrossRef] [PubMed]

17. Woods, C.K.; Brumme, C.J.; Liu, T.F.; Chui, C.K.; Chu, A.L.; Wynhoven, B.; Hall, T.A.; Trevino, C.; Shafer, R.W.; Harrigan, P.R. Automating HIV drug resistance genotyping with RECall, a freely accessible sequence analysis tool. J. Clin. Microbiol. 2012, 50, 1936-1942. [CrossRef] [PubMed]

18. Shafer, R.W. Rationale and uses of a public HIV drug-resistance database. J. Infect. Dis. 2006, 194 (Suppl. 1), S51-S58. [CrossRef]

19. Tamura, K.; Stecher, G.; Peterson, D.; Filipski, A.; Kumar, S. MEGA6: Molecular Evolutionary Genetics Analysis version 6.0. Mol. Biol. Evol. 2013, 30, 2725-2729. [CrossRef] [PubMed]

20. Illumina. Available online: https://www.illumina.com/content/dam/illumina-support/documents/ documentation/chemistry_documentation/16s/16s-metagenomic-library-prep-guide-15044223-b.pdf (accessed on 1 April 2018).

21. Magoc, T.; Salzberg, S.L. FLASH: Fast length adjustment of short reads to improve genome assemblies. Bioinformatics 2011, 27, 2957-2963. [CrossRef] [PubMed]

22. Babraham Bioinformatics. Available online: https://www.bioinformatics.babraham.ac.uk/projects/trim_ galore/ (accessed on 1 May 2018).

23. Armin, T.; Beerenwinkel, N. Available online: https://github.com/cbg-ethz/InDelFixer (accessed on 1 May 2018).

24. Li, H.; Handsaker, B.; Wysoker, A.; Fennell, T.; Ruan, J.; Homer, N.; Marth, G.; Abecasis, G.; Durbin, R.; 1000 Genome Project Data Processing Subgroup. The Sequence Alignment/Map format and SAMtools. Bioinformatics 2009, 25, 2078-2079. [CrossRef] [PubMed]

25. Barnett, D. Available online: https://github.com/pezmaster31/bamtools (accessed on 1 May 2018).

26. Tzou, P.L.; Ariyaratne, P.; Varghese, V.; Lee, C.; Rakhmanaliev, E.; Villy, C.; Yee, M.; Tan, K.; Michel, G.; Pinsky, B.A.; et al. Comparison of an in vitro Diagnostic Next-Generation Sequencing Assay with Sanger Sequencing for HIV-1 Genotypic Resistance Testing. J. Clin. Microbiol. 2018, 56. [CrossRef] [PubMed] 
27. Alidjinou, E.K.; Deldalle, J.; Hallaert, C.; Robineau, O.; Ajana, F.; Choisy, P.; Hober, D.; Bocket, L. RNA and DNA Sanger sequencing versus next-generation sequencing for HIV-1 drug resistance testing in treatment-naive patients. J. Antimicrob. Chemother. 2017, 72, 2823-2830. [CrossRef] [PubMed]

28. Huber, M.; Metzner, K.J.; Geissberger, F.D.; Shah, C.; Leemann, C.; Klimkait, T.; Böni, J.; Trkola, A.; Zagordi, O. MinVar: A rapid and versatile tool for HIV-1 drug resistance genotyping by deep sequencing. J. Virol. Methods 2017, 240, 7-13. [CrossRef] [PubMed]

29. Nykoluk, M.; Taylor, T. HyDRA Web User Guide 2016. Available online: https://hydra.canada.ca/HyDRA_ Web_User_Guide_Final_6Sept2016.pdf. (accessed on 1 May 2018).

30. Wirden, M.; Soulie, C.; Valantin, M.A.; Fourati, S.; Simon, A.; Lambert-Niclot, S.; Bonmarchand, M.; Clavel-Osorio, C.; Marcelin, A.G.; Katlama, C.; et al. Historical HIV-RNA resistance test results are more informative than proviral DNA genotyping in cases of suppressed or residual viraemia. J. Antimicrob. Chemother. 2011, 66, 709-712. [CrossRef] [PubMed]

31. Delaugerre, C.; Braun, J.; Charreau, I.; Delarue, S.; Nere, M.L.; de Castro, N.; May, T.; Marchou, B.; Simon, F.; Molina, J.M.; et al. Comparison of resistance mutation patterns in historical plasma HIV RNA genotypes with those in current proviral HIV DNA genotypes among extensively treated patients with suppressed replication. HIV Med. 2012, 13, 517-525. [CrossRef] [PubMed]

32. Derache, A.; Shin, H.S.; Balamane, M.; White, E.; Israelski, D.; Klausner, J.D.; Freeman, A.H.; Katzenstein, D. HIV drug resistance mutations in proviral DNA from a community treatment program. PLoS ONE 2015, 10. [CrossRef] [PubMed]

33. Keulen, W.; Boucher, C.; Berkhout, B. Nucleotide substitution patterns can predict the requirements for drug-resistance of HIV-1 proteins. Antivir. Res. 1996, 31, 45-57. [CrossRef]

34. Frost, S.D.; Nijhuis, M.; Schuurman, R.; Boucher, C.A.; Brown, A.J. Evolution of lamivudine resistance in human immunodeficiency virus type 1-infected individuals: The relative roles of drift and selection. J. Virol. 2000, 74, 6262-6268. [CrossRef] [PubMed]

35. Rimsky, L.; Vingerhoets, J.; Van Eygen, V.; Eron, J.; Clotet, B.; Hoogstoel, A.; Boven, K.; Picchio, G. Genotypic and phenotypic characterization of HIV-1 isolates obtained from patients on rilpivirine therapy experiencing virologic failure in the phase $3 \mathrm{ECHO}$ and THRIVE studies: 48-week analysis. J. Acquir. Immune Defic. Syndr. 2012, 59, 39-46. [CrossRef] [PubMed]

36. Nijhuis, M.; Schuurman, R.; de Jong, D.; Erickson, J.; Gustchina, E.; Albert, J.; Schipper, P.; Gulnik, S.; Boucher, C.A. Increased fitness of drug resistant HIV-1 protease as a result of acquisition of compensatory mutations during suboptimal therapy. AIDS 1999, 13, 2349-2359. [CrossRef] [PubMed]

37. Cane, P.A.; Kaye, S.; Smit, E.; Tilston, P.; Kirk, S.; Shepherd, J.; Hopkins, M.; Zhang, H.; Geretti, A.M. Genotypic antiretroviral drug resistance testing at low viral loads in the UK. HIV Med. 2008, 9, 673-676. [CrossRef] [PubMed]

38. Monie, D.; Simmons, R.P.; Nettles, R.E.; Kieffer, T.L.; Zhou, Y.; Zhang, H.; Karmon, S.; Ingersoll, R.; Chadwick, K.; Zhang, H.; et al. A novel assay allows genotyping of the latent reservoir for human immunodeficiency virus type 1 in the resting CD4 ${ }^{+}$T cells of viremic patients. J. Virol. 2005, 79, 5185-5202. [CrossRef] [PubMed]

39. Brennan, T.P.; Woods, J.O.; Sedaghat, A.R.; Siliciano, J.D.; Siliciano, R.F.; Wilke, C.O. Analysis of human immunodeficiency virus type 1 viremia and provirus in resting $\mathrm{CD} 4^{+} \mathrm{T}$ cells reveals a novel source of residual viremia in patients on antiretroviral therapy. J. Virol. 2009, 83, 8470-8481. [CrossRef] [PubMed]

40. Jung, A.; Maier, R.; Vartanian, J.P.; Bocharov, G.; Jung, V.; Fischer, U.; Meese, E.; Wain-Hobson, S.; Meyerhans, A. Recombination: Multiply infected spleen cells in HIV patients. Nature 2002, 418. [CrossRef] [PubMed]

41. Fraser, C. HIV recombination: What is the impact on antiretroviral therapy? J. R. Soc. Interface 2005, 2, 489-503. [CrossRef] [PubMed]

42. Chomont, N.; El-Far, M.; Ancuta, P.; Trautmann, L.; Procopio, F.A.; Yassine-Diab, B.; Geneviève, B.; Mohamed-Rachid, B.; Georges, G.; Brenchley, J.M.; et al. HIV reservoir size and persistence are driven by T cell survival and homeostatic proliferation. Nat. Med. 2009, 15, 893-900. [CrossRef] [PubMed]

43. Siliciano, J.D.; Kajdas, J.; Finzi, D.; Quinn, T.C.; Chadwick, K.; Margolick, J.B.; Kovacs, C.; Gange, S.J.; Siliciano, R.F. Long-term follow-up studies confirm the stability of the latent reservoir for HIV-1 in resting $\mathrm{CD}^{+}$T cells. Nat. Med. 2003, 9, 727-728. [CrossRef] [PubMed] 
44. Finzi, D.; Hermankova, M.; Pierson, T.; Carruth, L.M.; Buck, C.; Chaisson, R.E.; Quinn, T.C.; Chadwick, K.; Margolick, J.; Brookmeyer, R.; et al. Identification of a reservoir for HIV-1 in patients on highly active antiretroviral therapy. Science 1997, 278, 1295-1300. [CrossRef] [PubMed]

45. Wang, Y.M.; Dyer, W.B.; Workman, C.; Wang, B.; Peng, N.K.; Lachireddy, K.; Beng, C.C.; Sullivan, J.; Saksena, N.K. Drug resistance and viral evolution in plasma and peripheral blood cells during structured treatment interruption (STI) and non-interrupted HAART. Curr. HIV Res. 2007, 5, 235-250. [CrossRef] [PubMed]

46. Turriziani, O.; Andreoni, M.; Antonelli, G. Resistant viral variants in cellular reservoirs of human immunodeficiency virus infection. Clin. Microbiol. Infect. 2010, 16, 1518-1524. [CrossRef] [PubMed]

47. Nottet, H.S.; van Dijk, S.J.; Fanoy, E.B.; Goedegebuure, I.W.; de Jong, D.; Vrisekoop, N.; van Baarle, D.; Boltz, V.; Palmer, S.; Borleffs, J.C.; et al. HIV-1 can persist in aged memory CD4 ${ }^{+}$T lymphocytes with minimal signs of evolution after 8.3 years of effective highly active antiretroviral therapy. J. Acquir. Immune Defic. Syndr. 2009, 50, 345-353. [CrossRef] [PubMed]

48. Chew, C.B.; Potter, S.J.; Wang, B.; Wang, Y.M.; Shaw, C.O.; Dwyer, D.E.; Saksena, N.K. Assessment of drug resistance mutations in plasma and peripheral blood mononuclear cells at different plasma viral loads in patients receiving HAART. J. Clin. Virol. 2005, 33, 206-216. [CrossRef] [PubMed]

49. Liu, J.; Miller, M.D.; Danovich, R.M.; Vandergrift, N.; Cai, F.; Hicks, C.B.; Daria, J.H.; Feng, G. Analysis of low-frequency mutations associated with drug resistance to raltegravir before antiretroviral treatment. Antimicrob. Agents Chemother. 2011, 55, 1114-1119. [CrossRef] [PubMed]

50. El Bouzidi, K.; White, E.; Mbisa, J.L.; Sabin, C.A.; Phillips, A.N.; Mackie, N.; Pozniak, A.L.; Tostevin, A.; Pillay, D.; Dunn, D.T.; et al. HIV-1 drug resistance mutations emerging on darunavir therapy in PI-naive and -experienced patients in the UK. J. Antimicrob. Chemother. 2016, 71, 3487-3494. [CrossRef] [PubMed]

51. Kyeyune, F.; Gibson, R.M.; Nankya, I.; Venner, C.; Metha, S.; Akao, J.; Ndashimye, E.; Kityo, C.M.; Salata, R.A.; Mugyenyi, P.; et al. Low-Frequency Drug Resistance in HIV-Infected Ugandans on Antiretroviral Treatment Is Associated with Regimen Failure. Antimicrob. Agents Chemother. 2016, 60, 3380-3397. [CrossRef] [PubMed]

52. Messiaen, P.; Verhofstede, C.; Vandenbroucke, I.; Dinakis, S.; Van Eygen, V.; Thys, K.; Winters, B.; Aerssens, J.; Vogelaers, D.; Stuyver, L.J.; et al. Ultra-deep sequencing of HIV-1 reverse transcriptase before start of an NNRTI-based regimen in treatment-naive patients. Virology 2012, 426, 7-11. [CrossRef] [PubMed]

53. Fisher, R.; van Zyl, G.U.; Travers, S.A.; Kosakovsky Pond, S.L.; Engelbrech, S.; Murrell, B.; Scheffler, K.; Smith, D. Deep sequencing reveals minor protease resistance mutations in patients failing a protease inhibitor regimen. J. Virol. 2012, 86, 6231-6237. [CrossRef] [PubMed]

54. Liu, L.; Li, Y.; Li, S.; Hu, N.; He, Y.; Pong, R.; Lin, D.; Lu, L.; Maggie, L. Comparison of next-generation sequencing systems. J. Biomed. Biotechnol. 2012, 2012. [CrossRef] [PubMed]

55. Casadella, M.; Paredes, R. Deep sequencing for HIV-1 clinical management. Virus Res. 2017, $239,69-81$. [CrossRef] [PubMed]

56. Vandenbroucke, I.; Van Marck, H.; Mostmans, W.; Van Eygen, V.; Rondelez, E.; Thys, K.; Van Baelen, K.; Fransen, K.; Vaira, D.; Kabeya, K.; et al. HIV-1 V3 envelope deep sequencing for clinical plasma specimens failing in phenotypic tropism assays. AIDS Res. Ther. 2010, 7. [CrossRef] [PubMed]

(C) 2018 by the authors. Licensee MDPI, Basel, Switzerland. This article is an open access article distributed under the terms and conditions of the Creative Commons Attribution (CC BY) license (http:/ / creativecommons.org/licenses/by/4.0/). 